\title{
MENINGKATKAN KEMAMPUAN BERPIKIR KRITIS PADA PEMBELAJARAN GEOMETRI BERBASIS ETNOMATEMATIKA
}

\author{
Suhartini $^{1}$, Adhetia Martyanti ${ }^{2}$ \\ 1'suhartini86@gmail.com, ${ }^{2}$ adhetia.martyanti@yahoo.co.id \\ ${ }^{1,2}$ Program Studi Pendidikan Matematika \\ Universitas Alma Ata Yogyakarta \\ 2017
}

\begin{abstract}
Abstrak
Penelitian ini bertujuan untuk memaparkan bagaimana cara meningkatkan kemampuan berpikir kritis siswa pada pembelajaran menggunakan materi geometri berbasis etnomatematika. Metode yang digunakan dalam penelitian ini merupakan penelitian studi kepustakaan (library research). Data dalam penelitian ini merupakan data sekunder yang berupa hasil-hasil penelitian seperti buku-buku ilmiah, jurnal ilmiah, laporan penelitian, dan sumber lain yang relevan. Teknik analisis data dalam penelitian meliputi tiga tahapan, organize, synthesize, dan identify. Hasil penelitian ini menunjukkan bahwa etnomatematika memiliki relevansi dengan indikator pada kemampuan berpikir kritis, yang meliputi interpretasi, analisis, evaluasi, dan keputusan. Secara keseluruhan, disimpulkan bahwa kemampuan berpikir kritis siswa dapat ditingkatkan dengan menggunakan materi geometri berbasis etnomatematika dalam proses pembelajaran.
\end{abstract}

Kata kunci: geometri, berpikir kritis, etnomatematika

\begin{abstract}
This study aims to explain how to improve students' critical thinking skills on learning using materials based on ethnomathematics of geometry. The method used in this research is library research. The data in this study is secondary data in the form of research results such as scientific books, scientific journals, research reports, and other relevant sources. Data analysis techniques in this research include three stages, organize, synthesize, and identify. The results of this study indicate that ethnomathematics has relevance to indicators on critical thinking skills, which include interpretation, analysis, evaluation, and decision. Overall, it is concluded that students' critical thinking skills can be improved by using ethnomathematics-based geometry materials in the learning process.
\end{abstract}

Keywords: geometry, critical thinking, etnomathematics

\section{Pendahuluan}

Kurikulum 2013 mengembangkan pengalaman belajar yang memberikan kesempatan luas bagi para peserta didik untuk menguasai kompetensi dan memahami budaya Indonesia yang diperlukan bagi kehidupannya. Mempersiapkan peserta didik untuk kehidupan masa depan selalu menjadi kepedulian para 


\section{JURNAL GANTANG. September 2017; II(2): 105 - 111 \\ p-ISSN. 2503-0671 \\ e-ISSN. 2548-5547}

pendidik. Melalui kurikulum, maka usaha untuk mencapai tujuan pendidikan dalam rangka mempersiapkan kehidupan generasi muda bangsa menjadi lebih terarah. Permendiknas nomor 22 Tahun 2006 tentang standar isi menyatakan bahwa mata pelajaran matematika diberikan kepada semua peserta didik untuk membekali mereka dengan kemampuan berpikir logis, analitis, sistematis, kritis, dan kreatif, serta kemampuan bekerjasama. Berpikir kritis adalah proses berpikir yang memeriksa, menghubungkan, dan mengevaluasi semua aspek dari situasi atau masalah (Dewanti, S, S., 2015: 172). Termasuk didalamnya mengumpulkan, mengorganisir, mengingat, dan menganalisa informasi. Berpikir kritis termasuk kemampuan membaca dengan pemahaman dan mengidentifikasi materi yang dibutuhkan (Dewanti, S. S., 2015: 172). Lebih dari itu, berpikir kritis juga berarti mampu menarik kesimpulan dari data yang diberikan dan mampu menentukan ketidakkonsistenan serta pertentangan pada sekelompok data. Oleh sebab itu, peningkatan keterampilan berpikir kritis sangat diperlukan.

Geometri merupakan salah satu cabang matematika yang diajarkan mulai dari pendidikan dasar sampai perguruan tinggi. Geometri juga merupakan bidang yang sangat bermanfaat dalam kehidupan, sehingga geometri menjadi ilmu yang penting dipelajari secara lebih luas. Dari sudut pandang psikologi, geometri merupakan penyajian abstraksi pengalaman visual dan spasial, misalnya bidang, pola, pengukuran dan pemetaan. Sedangkan dari sudut pandang matematik, geometri menyediakan pendekatan-pendekatan pemecahan masalah, misalnya gambar-gambar, diagram, sistem koordinat, vektor, dan transformasi. Selain itu, diungkapkan oleh Burger \& Culpepper (1993: 140), bahwa geometri juga menjadi sarana untuk mempelajari struktur matematika. Sebab dalam geometri, siswa juga mempelajari serangkaian teorema dan membuktikannya.

Geometri menjadi salah satu materi yang menjadi perhatian utama dalam pelajaran 106 matematika. Adapun tujuan pembelajaran geometri secara umum adalah agar siswa memperoleh rasa percaya diri mengenai kemampuan (keterampilan) matematikanya, menjadi pemecah masalah yang baik, dapat berkomunikasi secara matematis, dan dapat bernalar secara matematis (Muhassanah, N., Sujadi, T., Riyadi, 2014: 55-56). Menurut pendapat lain, tujuan pembelajaran geometri adalah agar siswa memperoleh rasa percaya diri mengenai kemampuan matematikanya, menjadi pemecah masalah yang baik, dapat berkomunikasi secara matematik, dan dapat bernalar secara matematik (Bobango, 1993:148). Hal tersebut sejalan dengan pendapat Suydam yang menyatakan bahwa tujuan pembelajaran geometri adalah mengembangkan kemampuan berpikir logis, mengembangkan intuisi spasial mengenai dunia nyata, menenmkan pengetahuan yang dibutuhkan untuk matematika lanjut, dan mengajarkan cara membaca dan menginterpretasikan argument matematika (Clements \& Battista, 1992: 421).

Berdasarkan beberapa pendapat ahli tersebut, maka tujuan dari pembelajaran geometri diantaranya mengembangkan kemampuan pemecahan masalah dengan memanfaatkan pemikiran logis dan matematis. Pembelajaran geometri memberikan kesempatan kepada siswa untuk mengembangkan instuisi ruang pikiran dengan memasuki dunia geometri yang pada dasarnya sudah dikenal semenjak mereka masuk sekolah. Kemampuan pemecahan masalah dan imajinasi kreatif yang dikembangkan selama pembelajaran geometri membantu siswa dalam memahami konsepkonsep matematika lainnya.

Indonesia adalah Negara kepulauan atau sering juga disebut Nusantara. Terdapat beragam suku bangsa, bahasa, seni dan budaya, hingga kekayaan flora dan fauna di dalamnya. Khusus dalam hal seni dan budaya, Indonesia menyimpan banyak peninggalan sejarah yang bernilai seni tinggi, seperti candi Borobudur, candi Prambanan, Keraton, rumah adat dan sebagainya. Melalui budaya tersebut siswa juga 
dapat belajar matematika. Proses pembelajaran konsep matematika melalui kearifan budaya lokal sering disebut dengan istilah etnomatematika. Menurut D'Ambrosia (1994: 234), etnomatematika merupakan mode, gaya dan teknik menjelaskan, memahami dan menghadapi lingkungan alam dan budaya dalam sistem budaya yang berbeda. Etnomatematika juga bertujuan untuk mempelajari bagaimana peserta didik untuk memahami, mengartikulasikan, mengolah, dan akhirnya menggunakan ide-ide matematika, konsep, dan praktek-praktek tersebut dan diharapkan akan dapat memecahkan masalah yang berkaitan dengan aktivitas sehari-hari mereka (Putri, L., I, 2017: 23). Etnomatematika adalah suatu ilmu yang digunakan untuk memahami bagaimana matematika diadptasi dari sebuah budaya (Marsigit, 2016: 1-38).

Ketika kita mengingat hal tersebut, maka pembelajaran matematika yang menggunakan objek-objek budaya khususnya pada materi geometri dapat dijadikan bahan ajar untuk meningkatkan kemampuan berpikir krtitis pada siswa. Dimana, siswa dapat menginterpretasi, menganalisis, mengevaluasi, serta mampu menarik kesimpulan dari suatu permasalahan.

Melalui artikel ini, penulis akan memaparkan bagaimana meningkatkan kemampuan berpikir kritis melalui pembelajaran geometri berbasis etnomatematika. Dengan demikian, pembelajaran matematika khususnya geometri akan lebih menarik dan menyenangkan karena dikemas dalam praktik lapangan budaya.

\section{Metode Penelitian}

Metode yang digunakan dalam penelitian ini merupakan penelitian kepustakaan (library research). Dalam penelitian jenis ini, dikaji pengetahuan, gagasan, atau temuan yang terdapat didalam literatur sehingga memberikan informasi teoritis dan ilmiah terkait peran etnomatematika dalam pembelajaran geometri. Data yang dikumpulkan dan dianalisis merupakan data sekunder berupa hasil-hasil penelitian seperti buku-buku bacaan ilmiah, jurnal ilmiah, laporan penelitian, situs internet lainnya yang relevan. Selanjutnya, teknik analisis data dalam penelitian meliputi tiga tahapan, yaitu organize, synthesize, dan identify. Pertama, organize yakni mengorganisasikan literatur-literatur yang akan digunakan. Literatur yang digunakan terlebih dahulu di-review agar relevan/sesuai dengan permasalahan. Pada tahap ini penulis melakukan pencarian ide, tujuan, dan simpulan dari beberapa literatur dimulai dari membaca abstrak, pendahuluan, metode serta pembahasan serta mengelompokkan literatur berdasarkan kategori-kategori tertentu. Kedua, synthesize yaitu menyusun data yang diperoleh pada tahap pertama menjadi suatu ringkasan agar menjadi satu kesatuan yang padu, dengan mencari keterkaitan antar literatur. Ketiga, identify yakni mengidentifikasi data yang esensial dalam literatur. Data esesnsial yang dimaksud adalah data yang dianggap sangat penting untuk dibahas, agar memperoleh tulisan yang menarik untuk dibaca.penelitian.

\section{Pembahasan}

\section{Kemampuan Berpikir Kritis}

Kemampuan berpikir kritis merupakan salah satu kemampuan yang sangat diperlukan dalam setiap bidang kehidupan manusia. Oleh sebab itu, dalam setiap pembelajaran di sekolah, kemampuan berpikir kritis menjadi salah satu aspek yang sangat diperhatikan untuk dikembangkan pada setiap siswa. Berpikir kritis menekankan pada pemikiran yang rasional dan reflektif sehingga dapat mencapai proses pengambilan keputusan. Ini berarti ketika memecahkan suatu masalah perlu adanya pertimbangan yang masuk akal dan reflektif sehingga dapat mengambil keputusan tentang apa solusi yang tepat dan benar yang dapat digunakan untuk menyelesaikan masalah tersebut (Peter, E.E., 2012: 39-43).

Kemampuan berpikir kritis yaitu sebagai kemampuan berpikir reflektif, keterampilan menilai bukti suatu pernyataan, kemampuan menerapkan konsep untuk contoh-contoh baru mengenal kesenjangan dalam pengetahuan dan menemukan kesalahan dalam suatu argumen (Carrol \& Peden, 2008: 101). Berpikir kritis berfokus pada pemikiran yang reflektif dan yang diarahkan untuk menganalisis argumen tertentu, 


\section{JURNAL GANTANG. September 2017; II(2): 105 - 111 \\ p-ISSN. 2503-0671 \\ e-ISSN. 2548-5547}

mengakui kesalahan dan bias, dan mencapai kesimpulan berdasarkan bukti dan pertimbangan (Arends \& Klicher, 2010: 233). Menurut pendapat lain, kemampuan berpikir kritis sebagai kemamapuan dalam mengingat, menganalisis, memahami, mengaplikasi, menyimpulkan, evaluasi dan sintesis (Kuebli \& Korn, 2008: 142).

Berpikir kritis adalah proses pengujian atas klaim dan pendapat/argumen dan menentukan mana yang bermanfaat atau tidak. Siswa yang mampu berpikir kritis dapat mengevaluasi pikirannya dan membandingkannya dengan fakta atau pemikiran orang lain (Ruggerio, 2012: 20). Selanjutnya, dijelaskan tiga aktivitas dalam berpikir kritis yaitu (1) investigasi yang berkaitan dengan proses menemukan bukti atau suatu data yang merupakan pertanyaan kunci dari masalah; (2) interpretasi atau menafsirkan makna dari bukti secara masuk akal; (3) keputusan yang merupakan simpulan dari masalah (Ruggerio, 2012: 24).

Terdapat beberapa elemen-elemen penting dalam berpikir kritis yang harus dipelajari oleh siswa agar dapat memilki kemampuan berpikir kritis, yaitu: (1) mengidentifikasi masalah; (2) mengidentifikasi hubungan antara unsur-unsur; (3) menyimpulkan implikasi; (4) menyimpulkan motif;

menggabungkan unsur-unsur independen untuk menciptakan pola-pola baru yang dibuat dari pemikiran (kreativitas); dan (6) membuat interpretasi asli (Orlich, 2010: 287). Beberapa pedoman bagi guru dalam membantu peserta didik mengembangkan keterampilan berpikir kritis, yaitu: (1) guru harus berperan sebagai pemandu siswa dalam meyusun pemikiran mereka sendiri; (2) menggunakan pertanyaan yang berbasis pemikiran; (3) bangkitkan rasa ingin tahu intelektual siswa. Dorong siswa untuk bertanya, merenungkan, menyelidiki, dan meneliti; (4) libatkan siswa dalam perencanaan dan strategi; (5) beri siswa contoh pemikir yang positif dan kreatif; (6) guru harus mampu menjadi contoh pemikir yang positif bagi siswa (Santrock, 2007: 359).

Berpikir kritis dalam matematika dapat diinterpretasikan dalam berbagai cara. Berpikir kritis dalam matematika yaitu kemampuan dan disposisi untuk melibatkan pengetahuan sebelumnya, penalaran matematis, dan strategi kognitif untuk menggeneralisasi, membuktikan, atau mengevaluasi situasi matematika yang kurang dikenal dalam cara yang reflektif (Glazer, 2001: 13). Pendapat yang hampir serupa juga diungkapkan oleh Krulik dan Rudnick yaitu bahwa yang termasuk berpikir kritis dalam matematika meliputi kegiatan atau proses mempertanyakan,menguji, menghubungkan, mengevaluasi setiap aspek yang ada dalam masalah ataupun situasi tertentu (Fachrurazi, 2011: 81).

Seseorang yang berpikir kritis akan selalu peka terhadap informasi atau situasi yang sedang dihadapinya, dan cenderung bereaksi terhadap situasi atau informasi tersebut (Subandar, 2007: 5). Dengan demikian usaha untuk menumbuhkan kemampuan berpikir kritis dalam pembelajaran matematika berkaitan dengan usaha untuk menumbuhkan kepekaan siswa untuk mengumpulkan informasi dan menggunakannya untuk bereaksi terhadap situasi tersebut. Hal ini dapat dilakukan dengan cara menghadapkan siswa pada situasi tertentu sehingga siswa mampu mengkonstruksi pemikirannnya sendiri berdasarkan situasi tersebut (Shanti, W. N, Sholihah, D. A, Martyanti, A, 2017: 8). Pendapat tersebut senada dengan pendapat Krulik dan Rudnick yang mengungkapkan bahwa berpikir kritis tersebut bisa muncul apabila dalam pembelajaran adanya masalah yang menjadi pemicu dan diikuti dengan pertanyaan: Bagaimana menyelesaikan soal itu dengan cara yang lain", "Mengajukan pertanyaan bagaimana jika”, “Apa yang salah”, dan "Apa yang akan kamu lakukan"(Subandar, 2007: 8-9).

Berdasarkan pendapat-pendapat di atas dapat disimpulkan bahwa kemampuan berpikir kritis merupakan kemampuan berpikir tingkat 
tinggi yang terdiri dari elemen penting seperti menginterpretasi, menganalisis, mengevaluasi, serta membuat suatu keputusan untuk memecahkan masalah. Khusus dalam pembelajaran matematika, kemampuan berpikir kritis matematis berkenaan dengan pemecahan masalah matematika yang melibatkan pengetahuan, penalaran, dan pembuktian (Shanti, W. N, Sholihah, D. A, Martyanti, A, 2017: 8).

Dari pengertian di atas, dapat ditarik kesimpulan bahwa kemampuan berpikir kritis mencakup beberapa indikator antara lain: (1) interpretasi yaitu kemampuan memahami atau mengungkapkan makna dari data atau situasi yang disajikan dalam sebuah permasalahan matematika; (2) analisis yaitu kemampuan mengidentifikasi hubungan antara data yang diberikan dan menalar argumen yang diberikan; (3) evaluasi yaitu kemampuan menemukan dan membuktikan kesalahan dalam sebuah permasalahan matematika; (4) keputusan yaitu kemampuan membuat kesimpulan dari suatu permasalahan matematika.

\section{Pembelajaran Berbasis Etnomatematika}

Menurut Barton, etnomatematika merupakan kajian yang meneliti cara sekelompok orang dari budaya tertentu dalam memahami, mengekspresikan, dan menggunakan konsep-konsep serta praktik-praktik kebudayaannya yang digambarkan oleh peneliti sebagai sesuatu yang matematis (Barton, 1994: 196). Sedangkan menurut D'Ambrosio (D'Ambrosio, 1985: 44-48), mengatakan bahwa etnomatematika yang dipraktekkan diantara kelompok budaya diidentifikasi seperti masyarakat nasional suku, kelompok buruh, anak-anak dari kelompok usia tertentu dan kelas professional. Pendapat lainnya, dikatakan bahwa etnomatematika adalah suatu ilmu yang digunakan untuk memahami bagaimana matematika diadaptasi dari sebuah budaya dan berfungsi untuk mengekspresikan hubungan antara budaya dan matematika (Marsigit, 2016: 1-38). Sehingga dapat dikatakan bahwa ethnomatematika merupakan ilmu dalam mengkaji dan mengekspresikan kebudayaan masyarakat sekitar, peninggalan sejarah yang terkait dengan matematika dan pembelajaran matematika.

Dalam bidang matematika, etnomatematika muncul bukan karena kegagalan matematika modern, tetapi di dasarkan pada kesadaran baru tentang pengenalan potensi diri setiap kumpulan masyarakat. Belajar dan pembelajaran matematika, termasuk semua bentuk-bentuk pendidikan matematika, mau tidak mau akan dikelilingi oleh permasalahan yang terkait dengan budaya (Clements, 1996: 824). Sehingga bidang etnomatematika dapat digunakan sebagai pusat proses pembelajaran dan metode pengajaran, walaupun masih relatif baru dalam dunia pendidikan (Shirley, I.., 1995).

Candi, keraton, rumah adat merupakan beberapa objek budaya yang dapat dijadikan bahan ajar pembelajaran matematika khususnya pada materi geometri. Hal ini dikarenakan pada objek-objek tersebut terdapat banyak bentukbentuk geometri yang dapat terlihat dari bentuk relief-relief serta struktur bangunannya. Hadirnya etnomatematika dalam pembelajaran matematika memberikan nuansa bahwa belajar matematika tidak hanya dipelajari di dalam kelas tetapi di luar kelas dengan mengunjungi atau berinteraksi dengan kebudayaan setempat dan dapat digunakan sebagai media pembelajaran matematika ataupun bahan ajar khususnya pada materi geometri.

\section{Hubungan Kemampuan Berpikir Kritis pada Pembelajaran Geometri Berbasis Etnomatematika}

Pembelajaran geometri berbasis etnomatematika dapat dilakukan dengan cara pengkonstruksian pengalaman bermakna baik di dalam maupun di luar kelas yang memfokuskan pada budaya. Kegiatan ini dapat meningkatkan dan memperdalam pemahaman siswa dalam pembelajaran matematika melalui berbagai macam budaya. Pada bagian ini penulis memfokuskan beberapa indikator dari kemampuan berpikir kritis diantaranya interpretasi, analisis, evaluasi dan pembuatan keputusan pada pembelajaran geometri berbasis etnomatematika. 


\section{JURNAL GANTANG. September 2017; II(2): 105 - 111 \\ p-ISSN. 2503-0671 \\ e-ISSN. 2548-5547}

Pada tahapan pertama yaitu siswa ditugaskan untuk mendaftar sifat-sifat ataupun informasi yang ada pada situasi di lingkungan budaya sekitar. Pada saat itu, siswa ditugaskan untuk mengunjungi beberapa objek budaya seperti candi, keraton, rumah adat atau objek budaya lainnya agar dapat mengidentifikasi datadata obyek matematika berupa benda-benda kongkrit seperti gambar atau model bangun ruang, berwarna-warni lambang bilangan besar atau kecil, kolam berbentuk persegi, atap rumah berbentuk limas, kuda-kuda atap rumah berbentuk segitiga siku-siku dan seterusnya yang disajikan dalam sebuah permasalahan matematika (interpretasi).

Pada tahapan kedua, siswa diharapkan dapat mengidentifikasi hubungan antara benda atau objek yang ada di lapangan dan menalar argumen yang diberikan menggunakan sifat-sifat ataupun informasi pada benda-benda geometri yang sudah mereka ketahui, misalnya siswa mengamati dinding candi, berbentuk persegi panjang, kemudian siswa menguraikan sifat-sifat persegi panjang, mengukur panjang, lebar, lalu menghitung luas dan keliling benda tersebut.

Selanjutnya pada tahapan ketiga yaitu siswa mempresentasikan hasil penelitian yang telah dilakukan di depan kelas kemudian siswa yang lain memberikan umpan balik. Dalam diskusi tersebut, siswa juga dapat bertukar pertanyaan dengan siswa lain kemudian mencari solusi dari permasalahan yang ditemukan. Pada saat itu, siswa dapat melakukan crosscheck tentang informasi yang telah mereka peroleh dari proses sebelumnya. Siswa dapat menemukan dan membuktikan kesalahan dalam sebuah permasalahan matematika (evaluasi), baik yang berasal dari pertanyaan yang mereka buat maupun pertanyaan yang diperoleh dari siswa lain. Tahapan terakhir yaitu mengaplikasikan matematika, dimana siswa dituntut untuk menerapkan konsep matematika yang telah mereka temukan. Pada tahapan ini siswa membuat kesimpulan dari suatu permasalahan matematika, yang selanjutnyadapat digunakan untuk menyelesaikan permasalahan yang lain (keputusan).

\section{Penutup}

Berdasarkan uraian di atas, pembelajaran matematika berbasis etnomatematika diharapkan dapat meningkatkan kemampuan berpikir kritis siswa dalam meyelesaikan permasalahan geometri, dimana kemampuan berpikir kritis merupakan kemampuan berpikir tingkat tinggi yang terdiri dari elemen penting diantaranya menginterpretasi, menganalisis, mengevaluasi, serta membuat suatu keputusan untuk memecahkan suatu masalah. Khususnya bagi para siswa, etnomatematika akan membantu mereka dalam mempelajari, menganalisis dan memprektekkan kegiatan pembelajaran khususnya pada materi geometri dengan penggunaan pengejaran pemecahan masalah yang relevan dengan budaya sebagai bahan ajar dan alternatif dalam pembelajaran.

Dari penelitian ini, peneliti memberikan rekomendasi untuk penelitian lebih lanjut pada kemampuan berpikir kritis berbasis etnomatematika dalam materi lain, seperti statistika, aljabar, dan lain-lain.

\section{Daftar Pustaka}

Almatsier, Sunita. (2011). Gizi Seimbang Dalam Daur Kehidupan. Jakarta: Gramedia Pustaka Utama.

Ardiyaningrum, M. (2013). Upaya peningkatan kemampuan pemecahan masalah matematis siswa kelas VII SMP Muhammadiyah 9 Yogyakarta melalui penerapan pendekatan pembelajaran problem posing, Literasi Jurnal Ilmu Pendidikan 4(1): 53.

Devi, V. C., A. Sartono, dan J. T. Isworo, (2013). Praktek Pemilihan Makanan Kemasan Berdasarkan Tingkat Pengetahuan Tentang Label Produk Makanan Kemasan, Jenis Kelamin, dan Usia Konsumen di Pasar Swalayan ADA Setiabudi Semarang. Jurnal Gizi Universitas Muhammadiyah Semarang 2(2): 11 . 
Firdaus, F. M., Wahyudin, dan T. Hermawan. (2017). Improving primary students' mathematical literacy through problem based learning and direct instruction. Academicjournals 12(4):218.

Harris, H. dan M. Fadli. (2014). Penentuan umur simpan (shelf life) pundangseluang (rasbora sp) yang dikemas menggunakankemasan vakum dan tanpa vakum, Jurnal Saintek Perikanan 9 (2): 53.

Hasibuan, I. (2014). Model pembelajaran CTL. Logaritma 2 (01):11.

Hasnawati. (2006). Pendekatan contextual teaching learning hubungannya dengan evaluasi pembelajaran, Jurnal Ekonomi \& Pendidikan 3 (1): 53.

Herawati. (2008). Penentuan Umur Simpan Pada Produk Pangan. Jurnal Litbang Pertanian 27(4): 124.

Johar, R. (2012). Domain Soal PISA untuk Literasi Matematika. Jurnal Peluang 1(1): 32 .

Jufri, L. H. (2015). Penerapan Double Loop Problem Solving untuk Meningkatkan Kemampuan Literasi Matematika Level 3 pada Siswa Kelas VIII SMPN 27 Bandung. LEMMA 2(1): 56

Kadir, A. (2013). Konsep pembelajaran kontekstualdi sekolah, Dinamika Ilmu 13( 3): 36.

Koran Sindo. (2016). Pentingnya Membaca Label Pangan. 17 Maret.Halaman 29. Jakarta.

Lange, J. D. (2003). Mathematics For Literacy. Quantitative Literacy: Why Numeracy Matters for Schools and Collage. The National Council on Education and the Disciplines. Princeton.

Mahdiansyah dan Rahmawati. (2014). Literasi Matematika Siswa Pendidikan Menengah: Analisis Menggunakan Desain Tes Internasional Dengan Konteks Indonesia, Jurnal Pendidikan dan Kebudayaan 20 (4): 453

Murtiyasa, B. (2015). Tantangan Pembelajaran Matematika Era Global. Prosiding
Seminar Nasional Matematika dan Pendidikan Matematika. UMS: 39,

Noviani, K., E. Afifah, dan D. Astiti. (2016).

Kebiasaan jajan dan pola makan serta hubungannya dengan status gizi anak usia sekolah di SD Sonosewu Bantul Yogyakarta. Jurnal Gizi dan Dietetik Indonesia 4 (2): 98.

(OECD). 2010. PISA 2012 Matemathics Framework. PISA, OECD Publishing.Paris.

Paratmanitya, Y. dan V. Aprilia. (2016). Kandungan bahan tambahan pangan berbahaya pada makanan jajanan anak sekolah dasar di Kabupaten Bantul. Jurnal Gizi dan Dietetik Indonesia 4(1): 55.

Sari, R. H. N. (2015). Literasi matematika: Apa, Mengapa, dan Bagaimana? Prosiding Seminar Nasional Matematika dan Pendidikan Matematika. UNY:719.

Thomson, S., K. Hillman, dan L. D. Bortoli. (2013). A Teacher's Guide to PISA Mathematical Literacy.ACER Press. Australia.

Sugiman, (2008), Pandangan matematika sebagai aktivitas insani beserta dampak pembelajarannya, Jurnal pendidikan matematika 2(2): 64-70. 
JURNAL GANTANG. September 2017; II(2): 105 - 111 p-ISSN. 2503-0671

e-ISSN. 2548-5547 